\title{
CLINICO-MICROBIOLOGICAL PROFILE OF INFECTIVE KERATITIS IN A TERTIARY CARE HOSPITAL, EASTERN INDIA
}

\author{
Bimoch Projna Paty, Maitreyi T, Sanghamitra Padhi, Banojini Parida \\ Department Of Microbiology, MKCG Medical College, Berhampur, Orissa, India.
}

\section{ABSTRACT}

Background: Infective Keratitis (Microbial Keratitis) is infection of the cornea caused by a wide spectrum of microbial agents. Its main clinical presentation is Corneal ulcer that is defined as a loss of corneal epithelium. According to World health organization (WHO), corneal diseases are among the major causes of vision loss and blindness in the world today, second only to cataract in overall importance. Aim: To isolate and identify the pathogenic organism Method: The study was conducted in 45 patients diagnosed with corneal ulcer attending Ophthalmology OPD, MKCG Medical College and Hospital, Berhampur over a period of 2 months. The material was scraped from the leading edge and base of the ulcer and was inoculated onto Blood agar, Mac conkey agar and Sabouraud Dextrose agar for culture and onto 2 slides for Gram's stain and 10\% KOH wet mount. The susceptibility testing was done by Kirby Bauer's disc diffusion method. Results: Out of total 45 patients,35were males. Majority of the patients belonged to age group of 50-60 years. Pain, Redness, Hypopyon was most commonly seen in Bacterial keratitis. In Fungal Keratitis, Redness (80\%), Blurred vision (80\%) was seen. Most common occupation was Farmers (66.6\%). Trauma was the most common risk factor (23 isolates). Majority were bacterial isolates (29 isolates, 64.4\%) followed by fungal (5 isolates ,11.1\%). Predominant isolate was Staphylococcus aureus (68.9\%). All the gram- positive isolates showed 100\% senitivity to Linezolid and Vancomycin. Conclusion: Knowledge of local prevalence of etiological agents of IK and their susceptibility patterns helps in guiding ophthalmologists to select appropriate antibiotic for empirical therapy

Keywords: Keratitis; Bacterial keratitis; Staphylococcus aureus; MRSA.

\section{INTRODUCTION}

Infective Keratitis (Microbial Keratitis) is infection of the cornea caused by a wide spectrum of microbial agents which is a potentially sight threatening condition $[1,2]$. According to World health organization (WHO), corneal diseases are among the major causes of vision loss and blindness in the world today, second only to cataract in overall importance [3].

WHO has perceived that corneal blindness due to microbial keratitis is emerging as principal reason for visual inability and that it is "Silent Epidemic" happening unnoticed around the world. Its main clinical presentation is corneal ulcer that is defined as a loss of corneal epithelium with infiltration and suppuration of underlying stroma accompanied with signs of inflammation with or without hypopyon. The etiological and epidemiological features of Infective keratitis depend on host factors, geographical location, and climate also tends to vary with time. Hence, epidemiological features, risk factors and etiological agents that occur in a specific region are important in rapid diagnosis of the disease and timely institution of specific therapy. In order to start specific therapy, it is

DOI: $10.31878 /$ ijcbr.2019.54.04

necessary to do microbial investigations which includes microscopy and culture for identification.

\section{MATERIAL AND METHODOLOGY}

Study design: Prospective study

Study place: The study was conducted in 45 patients diagnosed with corneal ulcer attending Ophthalmology OPD, MKCG Medical College and Hospital, Berhampur

Ethical approval: Consent was taken for collection of corneal scrapings and the study procedures were approved by Institutional ethics committee

Time frame: over a period of 2 months from January to March 2019

Inclusion criteria: All Suspected Bacterial and Fungal infected corneal ulcers

Exclusion criteria: Marginal keratitis, Interstitial keratitis, suspected viral ulcers.

Sample size: 45 samples

Methodology : History was taken like age, sex, occupation, history of trauma, surgery and antibiotic intake. Corneal scrapings were taken after complete ocular examination under slit lamp biomicroscope, with strict aseptic precautions using a sterile (Number-15) Bard-Parker blade. Before the collection, 4\% paracaine

Correspondence: Maitreyi T, Department Of Microbiology, MKCG Medical College, Berhampur, Orissa, India. Email: tadepalli.maitreyi@gmail.com 
was instilled without preservative. Consent was taken for collection of corneal scrapings

The material was scraped from the leading edge and base of the ulcer and was inoculated onto Blood agar, Mac Conkey agar and Sabouraud Dextrose agar for culture and onto two slides for Gram's stain and 10\% $\mathrm{KOH}$ wet mount [4]. All the inoculated Bacteriological media were incubated at $37^{\circ} \mathrm{C}$.

Identification of the organisms was done by following standard protocols. The susceptibility testing was done by Kirby Bauer's [5] disc diffusion methods as per Clinical and Laboratory Standards Institute guidelines. Cefoxitin (30 microgram disk) was also given to study Methicillin Resistance Staphylococcus aureus by disk diffusion method according to CLSI guidelines [6].

Inoculated Sabouraud Dextrose Agar (SDA) was incubated at $27^{\circ} \mathrm{C}$ and were examined daily until three weeks for growth. Fungi were identified by their colony characteristic on Sabouraud dextrose agar and morphological character on Lactophenol cotton blue mount.

\section{RESULTS}

Out of a total of 45 patients, $35(77.7 \%)$ were males, and $10(22.2 \%)$ were females. The most common occupation was Farmers (66.6\%) followed by labourers $(22.2 \%)$, Housewife (11.1).

Table 1:Age group of the patients $(n=45)$

\begin{tabular}{ll}
\hline Age group (years) & Number of patients (\%) \\
\hline $10-20$ & $2(4.4)$ \\
$21-30$ & $3(6.6)$ \\
$31-40$ & $4(8.8)$ \\
$41-50$ & $6(13.3)$ \\
$51-60$ & $15(33.3)$ \\
$61-70$ & $7(15.5)$ \\
$71-80$ & $8(17.7)$ \\
\hline
\end{tabular}

Majority of the patients belonged to age group of 50-60 years $(33.3 \%)$.

Pain (93.1\%), Redness (89.6\%), Hypopyon (72.4\%), Lacrimation $(86.2 \%)$ was most commonly seen in Bacterial keratitis. In Fungal keratitis, Redness (80\%), Blurred/Diminished vision (80\%), Pain $(60 \%)$ was seen (Table 2).

Table 2: Clinical features

\begin{tabular}{|c|c|c|}
\hline Clinical features & $\begin{array}{l}\text { Bacterial kera- } \\
\text { titis }(\mathrm{N}=29)\end{array}$ & $\begin{array}{l}\text { Fungal ker- } \\
\text { atitis }(\mathrm{N}=5)\end{array}$ \\
\hline \multicolumn{3}{|l|}{ Symptom } \\
\hline Redness & $26 / 29(89.6 \%)$ & $4 / 5(80 \%)$ \\
\hline Pain & $27 / 29(93.1 \%)$ & $3 / 5(60 \%)$ \\
\hline Lacrimation & $25 / 29(86.2 \%)$ & $3 / 5(60 \%)$ \\
\hline Photophobia & $27 / 29(93.1 \%)$ & $2 / 5(40 \%)$ \\
\hline $\begin{array}{l}\text { Blurred/Diminished } \\
\text { vision }\end{array}$ & $20 / 29(68.9 \%)$ & $4 / 5(80 \%)$ \\
\hline \multicolumn{3}{|l|}{ Signs } \\
\hline Lid oedema & $20 / 29(68.9 \%)$ & $1 / 5(50 \%)$ \\
\hline Hypopyon & $21 / 29(72.4 \%)$ & $2 / 5(40 \%)$ \\
\hline $\begin{array}{l}\text { Conjunctival con- } \\
\text { gestion }\end{array}$ & $16 / 24(66.6 \%)$ & $3 / 5(60 \%)$ \\
\hline $\begin{array}{l}\text { Irregular feathery } \\
\text { margins }\end{array}$ & $12 / 24(50 \%)$ & $4 / 5(80 \%)$ \\
\hline
\end{tabular}

Table 3: Risk factors $(n=45)$

\begin{tabular}{ll}
\hline Risk factor & No. of isolates \\
\hline Trauma & $23(51.1)$ \\
H/O antibiotic intake & $5(11.1)$ \\
Prior surgery & $6(13.3)$ \\
H/O Diabetes mellitus & $4(8.8)$ \\
Contact lens wear & $3(6.6)$ \\
Pre-existing ocular disease & $4(8.8)$ \\
\hline
\end{tabular}

Trauma was the most common risk factor (23 isolates, $51.1 \%$ ) followed by History of Prior surgery (13.3\%).

Table 4: Types of isolate $(n=45)$

\begin{tabular}{ll}
\hline Organism isolated & Number of isolates (\%) \\
\hline Bacterial & $29(64.4)$ \\
Fungal & $5(11.1)$ \\
Sterile & $11(24.4)$ \\
\hline
\end{tabular}

Majority were Bacterial isolates (29 isolates,64.4\%) followed by fungal (5 isolates ,11.1\%).

Table 5: Bacterial isolates $(n=29)$

\begin{tabular}{ll}
\hline Bacteria isolated & Number (\%) \\
\hline Staphylococcus aureus & $20(68.9)$ \\
Enterococcus spp. & $3(10.3)$ \\
Pseudomonas aeruginosa & $4(13.7)$ \\
Acinetobacter baumanii & $2(6.8)$ \\
\hline
\end{tabular}

Predominant isolate was Staphylococcus aureus (68.9\%) followed by Pseudomonas aeruginosa. (13.7\%).

Table 6: Fungal isolates $(n=5)$

\begin{tabular}{ll}
\hline Fungus isolated & Number (\%) \\
\hline Fonsacea pedrosoi & $1(20)$ \\
Fusarium & $2(40)$ \\
Aspergillus fumigatus & $1(20)$ \\
Candida albicans & $1(20)$ \\
\hline
\end{tabular}

Majority of the isolates were filamentous fungi (80\%).

Table 7: Sensitivity Pattern of Gram- positive cocci

\begin{tabular}{lll}
\hline Bacterial isolate & $\begin{array}{l}\text { Staphylococ- } \\
\text { cus aureus }\end{array}$ & $\begin{array}{l}\text { Enterococ- } \\
\text { cus spp. }\end{array}$ \\
\hline Linezolid & $20 / 20(100 \%)$ & $3 / 3(100 \%)$ \\
Vancomycin $(30 \mu \mathrm{g})$ & $20 / 20(100 \%)$ & $3 / 3(100 \%)$ \\
Ciprofloxacin $(5 \mu \mathrm{g})$ & $11 / 20(55 \%)$ & $2 / 3(66 \%)$ \\
Cefoxitin $(30 \mu \mathrm{g})$ & $10 / 20(50 \%)$ & - \\
Gentamycin $(10 \mu \mathrm{g})$ & $13 / 20(65 \%)$ & $1 / 3(33 \%)$ \\
Moxifloxacin $(5 \mu \mathrm{g})$ & $14 / 20(70 \%)$ & $2 / 3(66 \%)$ \\
\hline
\end{tabular}

All the gram- positive isolates showed $100 \%$ senitivity to Linezolid and Vancomycin. Out of 20 isolates of Staphylococcus aureus 14 isolates were sensitive to Moxifloxacin $(70 \%)$ followed by Gentamycin (13 isolates, $65 \%$ ), Ciprofloxacin(11 isolates, $55 \%$ ) .

Table 8: Sensitivity pattern of Gram-negative bacilli

\begin{tabular}{|c|c|c|}
\hline Bacterial isolate & $\begin{array}{l}\text { Acineto- } \\
\text { bacter bau- } \\
\text { manii }\end{array}$ & $\begin{array}{l}\text { Pseudomo- } \\
\text { nas aeru- } \\
\text { ginosa }\end{array}$ \\
\hline Ciprofloxacin(5mcg) & $1 / 2(50 \%)$ & $1 / 4(25 \%)$ \\
\hline Gentamycin $(10 \mathrm{mcg})$ & $2 / 2(100 \%)$ & $2 / 4(50 \%)$ \\
\hline $\begin{array}{l}\text { Piperacillin tazobac- } \\
\operatorname{tam}(100 / 10 \mathrm{mcg})\end{array}$ & - & $3 / 4(75 \%)$ \\
\hline Levofloxacin $(5 \mathrm{mcg})$ & $2 / 2(100 \%)$ & $1 / 4(25 \%)$ \\
\hline Moxifloxacin $(5 \mathrm{mcg})$ & $1 / 2(50 \%)$ & $3 / 4(75 \%)$ \\
\hline Tobramycin $(10 \mathrm{mcg})$ & $1 / 2(50 \%)$ & $2 / 4(50 \%)$ \\
\hline
\end{tabular}


Pseudomonas aeruginosa was sensitive to Piperacillin tazobactam (3 isolates, 75\%), Moxifloxacin (3 isolates, $75 \%)$.

\section{DISCUSSION}

At birth the eyes are sterile but soon become invaded by microorganisms. The interior structures remain sterile. Almost any bacterial species can infect the cornea if the integrity of the natural anatomic barriers or defence mechanisms is compromised [4]. Despite therapeutic advances in the treatment of $\mathrm{IK}$, it continues to be a major cause of blindness, especially in developing nations.

Higher incidence was seen in age group 50-60 years $(33.3 \%)$ in our study similar to Gopinathan et.al [8].

History of male preponderance $(77 \%)$ has been reported by our study which is similar to study done by Bashir et.al. [9] (65\%). However, Al Yousouf N et.al [10] and Kotigadde S et.al [11] reported higher incidence among women. The male predominance is due to their outdoor activities in the age group of 50-60 years thus predisposing to trauma and corneal infections.

Farmers and labourers are in constant contact with vegetative matter and thus prone to corneal ulcers. This may be the reason for highest incidence of corneal ulcers in farmers and labourers as compared to various other occupation similar to study done by Srinivasan et $\mathrm{al}^{12}$.

Majority of the research work recorded trauma as a major risk factor in India. Trauma (51.1\%) was the most common predisposing risk factor in our study similar to Srinivasan et.al [12]. However, Shaefer et.al [13] (Switzerland) and Green et.al [14] (Australia) have reported contact lens as the most common risk factor for development of keratitis. This difference can be explained as the study was carried out in a developed country, where more people use contact lenses and history of occupational trauma is uncommon due to increased awareness and occupational safety measures.

In the present study, the Patient presented with clinical features of Pain 93.1\%, Redness 89.6\%and Hypopyon $72.4 \%$ in Bacterial keratitis. In Fungal keratitis, Blurred/ Diminished vision $80 \%$, Pain $60 \%$ and Redness $80 \%$ was seen which can be compared to the study done by Ibrahim et al [15] and Thomas et.al [16] (Red eye Bacterial $89.22 \%$ fungal $87 \%$, Pain - Bacterial $90.32 \%$ Fungal $87.55 \%$, Photophobia-Bacterial $67.74 \%$ Fungal 86.67\%, Poor vision -Bacterial 71.67\% Fungal-93.49\%, Hypopyon (Bacterial 36\% Fungal 16\%).

In our study we observed culture positivity in 34 (75\%) of the 45 cases of clinically diagnosed infective keratitis and 11 cases were sterile which matches with reports of Srinivasan et.al [12]. The culture negativity may be due to that these patients may have received prior antibiotic treatment.

Majority of the cases had corneal infection by single agent the most common being bacterial in 29 cases $(64.4 \%)$. However, Sirisha et al [17], concluded that fungal corneal ulcer $(49 \%)$ is more common than bacterial corneal ulcer $(21 \%)$.

Bacterial keratitis was predominantly caused by Gram positive bacteria. The incidence of gram-positive cocci $(79 \%)$ coincides with the study done by Tewari et.al [18]. Predominance of Staphylococcus aureus was seen which is similar to a study done from Gangetic West Bengal [19]. However, Streptococcus pneumoniae was the predominant species in the study done by Bharathi et.al. [20].

$P$. aeruginosa is the predominant gram-negative bacteria that causes Corneal ulceration. In our study $P$. aeruginosa accounted for $13.7 \%$ of bacterial isolates which matches with the results of Kaliamurthy et al [21] (9.7\%). but G. Singh et al [22], Asbell PA et.al. [23], Houang E et.al [24] isolated higher number of Pseudomonas aeruginosa isolates which may be due to climatic conditions difference.

Fungal growth was seen in $11 \%$ of total corneal ulcers. Filamentous fungi are the major fungal pathogens in corneal ulcer in our study. Yeast like fungi have low predominance in fungal corneal ulcers. Fusarium species was the predominant fungal isolate in our study similar to the study done by Sirisha et.al [17]. However, Laspina et al [25] found that Acremonium species was the most commonly identified fungi (40\%) followed by Fusarium species (15\%) which can be attributed to difference in geographic location and environmental factors between India and Paraguay.

Both gram-positive and gram-negative isolates showed varied susceptibilities to selected antibiotics. Antibiotic resistance among ocular pathogens is increasing in parallel with the increase seen among systemic pathogens and likewise may have serious consequences such as development of sight-threatening complications of keratitis, endophthalmitis, orbital cellulitis, or panophthalmitis [23]. Our antibiotic sensitivity results were quite comparable to studies done by Sharma et.al [26], where the most common effective drug was Ciprofloxacin $(75 \%)$ followed by Gentamicin. In the present series, only $70 \%$ of organisms Staphylococcus aureus were susceptible to moxifloxacin, the 4th generation fluoroquinolone. Researchers have documented significantly increasing resistance rates to moxifloxacin among Staphylococcus aureus. Thirteen $(56.5 \%)$ of staphylococcal isolates were MRSA. Majority of isolates of $\mathrm{P}$. aeruginosa were sensitive to Moxifloxacin $(75 \%)$ which is similar with the reports of Kaliamurthy J. et.al [27].

Finding of low resistance levels to these newer fluoroquinolones highlights the need to use them for first line monotherapy in BK. However, Moss et al [28] reported $100 \%$ sensitivity of moxifloxacin and Gatifloxacin against both gram-positive and gramnegative bacteria.

\section{CONCLUSION}

Understanding the geographical pattern of the pathogenic organisms responsible and the identification of risk factors, helps to create a broad strategy for the diagnosis and management of corneal ulcers and helps in guiding ophthalmologists to select appropriate antibiotic for empirical therapy. Confirmation by microbiological diagnosis is very essential in order to limit the ocular morbidity and prevent complications.

Conflict of interest : Nil 
Source of funding : Nil

\section{REFERENCES}

[1] Andrew A. Dahl F. Keratitis: Read about Symptoms and Infection Treatment [Internet]. Medicine Net. 2014 Available from: http://www.medicinenet.com/ keratitis/article.htm

[2] Srinivas Jampala. Epidemiological and microbiological profile of infective keratitis in a tertiary care centre south India. Asian Journal of Biomedical and Pharmaceutical Sciences; 2014;4(37): 44-51

[3] Global initiative for the elimination of avoidable blindness. WHO: Geneva; 1997. (unpublished document) WHO/PBL. 97-61

[4] Lily Therese K, Madhavan HN. Microbiological procedures for diagnosis of ocular infections. Indian Journal of Medical Microbiology. 2006:1-47.

[5] Bailey and Scott. Role of microscopy in the diagnosis of infectious diseases. In: Forbes BA, Sahm DF, Weissfeld AS. Diagnostic Microbiology. $11^{\text {th }}$ Edition, Chapter-9, Mosby. 2002;122-23

[6] Milne LJR. Fungi. In: Colle JG, Fraser AG, Marmion BP, Simmons A. Mackie and McCartney Practical Medical Microbiology. 14th Edition, Chapter 41, Churchill Living stone 1996;95-100

[7] CLSI (2019) Performance standards for antimicrobialsusceptibility testing; Twenty nine informational supplement CLSI document M100-S23. Clinical and Laboratory Standards Institute, Wayne, PA

[8] Gopinathan U, Garg P, Fernandes M, Sharma S, Athmanathan S, Rao GN. The epidemiological features and laboratory results of fungal keratitis: a 10 -year review at a referral eye care centre in south India. Cornea 2002; 21:555-9

[9] Bashir G, Shah A, Thokar MA, Rashid S, Shakeel S. Bacterial and fungal profile of corneal ulcers: A prospective study. Indian J Pathol Microbiol 2005; 48:273-7

[10] Al-Yousuf N. Microbial keratitis in kingdom of Bahrain: clinical and microbiology study. Middle East Afr J Ophthalmol. 2009;16(1):3-7

[11] Kotigadde S, Ballal M, Jyothirlatha null, Kumar A, Srinivasa R, Shivananda PG. Mycotic keratitis: a study in coastal Karnataka. Indian J Ophthalmol. 1992;40(1):31-3

[12] Srinivasan M, Gonzales CA, George C. Epidemiology and aetiological diagnosis of corneal ulceration in Madurai, south India. Br J Ophthalmol 1997; 81:96571

[13] Schaefer F, Bruttin O, Zografos L, Crosier YG. Bacterial keratitis: a prospective clinical and microbiological study. Br J Ophthalmol 2001; 85:8427

[14] Green M, Apel A, Stapleton F. Risk factors and causative organisms in microbial keratitis. Cornea 2008; 27:22-27.

[15] Ibrahim MM, Vanini R, Ibrahim FM, Fioriti LS, Furlan EMR, Rovinzano LMA, De Castro RS, E Faria $\mathrm{E}$ et al., Epidemiologic aspects and clinical outcome of fungal keratitis in southeastern Brazil. E Journal Ophthalmol. 2009; 19(3):355-61

[16] Thomas PA, Leck AK, Myatt M. Characteristic clinical features as an aid to the diagnosis of suppurative keratitis caused by filamentous fungi. $\mathrm{Br}$ J Ophthalmol. 2005; 89(2):1554-8

[17] Sirisha T, Jayalakshmi L, Ratnakumari G, Viswamitra P. Microbiological Profile and Their Antimicrobial Susceptibility in Infective Keratitis at Regional Eye Hospital, Visakhapatnam. Scholars J. Appl. Med. Sci., 2015;3(3A): 1083-8

[18] Tewari A, Sood N, Vegad MM, Mehta DC. Epidemiological and microbiological profile of infective keratitis in Ahmedabad. Indian J Ophthalmol 2012; 60:267-72

[19] Basak SK, Basak S, Mohanta A, Bhowmick A. Epidemiological and microbiological diagnosis of suppurative keratitis in gangetic West Bengal, Eastern India. Indian J Ophthalmol. 2005; 53:17-22

[20] Bharathi MJ, Ramakrishnan R, Vasu S, Meenakshi R, Shivkumar C, Palaniappan R. Epidemiology of bacterial keratitis in a referral centre in south India. Indian J Med Microbiol 2003;21:239-45

[21] Kaliamurthy J, Kalavathy CM, Parmar P, Nelson Jesudasan CA, Thomas PA. Spectrum of Bacterial Keratitis at a Tertiary Eye Care Centre in India. BioMed Research International. 2013:1-8

[22] Singh G, Palanisamy M, Madhavan B, Rajaraman R, Narendran K, Kour A. Multivariate analysis of childhood microbial keratitis in South India. Ann Acad Med Singap. 2006;35(3):185-9

[23] Asbell PA, Colby KA, Deng S. Ocular TRUST: nationwide antimicrobial susceptibility patterns in ocular isolates. American Journal of Ophthalmology. 2008;145(6):951-8

[24] Houang E, Lam D, Fan D, Seal D. Microbial keratitis in Hong Kong: relationship to climate, environment and contact-lens disinfection. Transactions of the Royal Society of Tropical Medicine and Hygiene. 2001;95(4):361-7

[25] Laspina F, Samudio M, Cibils D. Epidemiological characteristics of microbiological results on patients with infectious corneal ulcer: a 13 year survey in Paraguay. Graefes Arch Clin Exp Ophthalmol 2004;242(3):204-9

[26] Sharma S, Taneja M, Gupta R. Comparison of clinical and microbiological profiles in smear positive and smear negative cases of suspected microbial keratitis. Ind J Ophthalmol 2007; 55:21-5

[27] Kaliamurthy J, Nelson Jesudasan CA, Geraldine P, Parmar P, Kalavathy CM, Thomas PA. Comparison of in vitro susceptibilities of ocular bacterial isolates to gatifloxacin and other topical antibiotics. Ophthalmic Res. 2005;37(3):117-22

[28] Moss JM, Sanislo SR, Ta CN. Antibiotic susceptibility patterns of ocular bacterial flora in patients undergoing intravitreal injections. Ophthalmology. 2010;117(11): 2141-5 